\title{
Human Experiments: Past, Present and Future
}

\author{
Ankit Raj ${ }^{1}$ \\ ${ }^{1}$ Final Year MBBS, Kasturba Medical College, Manipal
}

\begin{abstract}
Human experimentation is systematic, scientific investigation that can be either interventional or observational and involves human beings as research subjects. The most pivotal question in research ethics is not whether we should be doing research and experimentations on humans but can we justify exposing individuals to risks associated with it, just for the sake of progression of medicine- is addressed in this article. It is of paramount importance that pros and cons be balanced before the start of any study and correct procedures followed for every step of the research and human experimentation, keeping mind the ethics involved.
\end{abstract}

Key Words: human experimentation, research, ethics.

"Better not perceive yourselves too high, O humans. We only value mankind as our experimentation object"

Toba Beta

Human experimentation is systematic, scientific investigation that can be either interventional or observational and involves human beings as research subjects [1]. Human experimentations are controversial because it interferes with the inherent dignity and fundamental rights of humans [2]. The most pivotal question in research ethics is not whether we should be doing research and experimentations on humans but can we justify exposing individuals to risks associated with it, just for the sake of progression of medicine.

History is riddled with stomach-turning, mind-unsettling stories of human experimentation. In 1796, Edward Jenner inoculated smallpox virus into an unknowing 8 year old boy, himself aware of its lethality yet unfazed. The oldest and most commonly used human cell line, HeLa cells, instrumental for research into Polio, Cancer, AIDS and gene mapping was isolated from Henrietta Lacks, an unsuspecting uneducated, poor African-American women from Baltimore, who died penniless and without even a tombstone. In 1940s, to test the effectiveness of Penicillin as a cure for Syphilis, US conducted unethical human experimentations in Guatemala. In this $\mathrm{NIH}$ funded experiment, doctors paid prostitutes infected with syphilis to have sex with prisoners, asylum patients and soldiers and when this didn't work, they inoculated syphilis bacteria onto men's penises and on their forearms and faces. The Genetic Studies of Genius, started by Lewis Terman at Stanford University to disprove the then-current belief that gifted 
children were sickly, socially inept, and not well-rounded, is now the oldest and longest running longitudinal study in the world [3]. This study has often been criticized for not having a generalized sample, as selection was based on recommendations and largely constituted of children from white and upper or middle class families [4]. Furthermore, Terman meddled in his subjects' lives by giving them letter of recommendations and pulling strings to get them admitted to Ivy League schools [5-7].

At the end of the Second World-War and after the conclusion of the Doctor's trial in Nuremberg, as a response to horrors of human experimentation done in Nazi Germany, a set of rules governing what was legal and what was not during any human experimentation was devised. The Nuremberg Code contained a list of 10 research ethics principles such as informed consent and absence of coercion; properly formulated scientific experimentation; and beneficence towards experiment participants [8-9]. Declaration of Geneva and Universal Declaration of Human Rights built up on these founding principles to bring under its ambit several other medical crimes and human rights violation.

"We slow the progress of science today for all sorts of ethical reasons. Biomedicine could advance much faster if we abolished our rules on human experimentation in clinical trials, as Nazi researchers did."

Paul Nitze

While the above quote is a reminiscent of Cold War ideology, the world is still not too far from rampant practice of unethical and questionable human experimentations. In 2002, the United States Office for Human Research Protections (OHRP) suspended nearly all federally funded medical research involving human subjects at Johns Hopkins University, after investigation of death of a previously healthy volunteer [10]. In 2014, during a trial for an experimental vaccine against Rotavirus in India, 2000 children received placebo in spite of presence of two highly efficacious vaccines already in the market [11].

The setting up of Institutional Review Board (IRB) with the purpose to protect the rights and welfare of humans participating as subjects in a research study is a step in the right direction. Also known as Independent Ethics Committee (IEC), its functions are to approve, monitor and review biomedical and behavioral research involving humans as subjects and to conduct riskbenefit analysis wherever required. Another decisive step in human experimentation was taken recently with the development of Organs-on-Chips by Wyss Institute at Harvard [12]. Organs-onChips are engineered microchips that recapitulate the microarchitecture of living organs such as heart and lungs and can be used to rapidly assess response of new drug or therapy without using humans or animals as research subjects.

While it may still be a long time before a considerable progress is made in ethical practice of human experimentation, it is of paramount importance that pros and cons should be balanced before the start of any study and correct procedures followed for every step of the research.

"The first step in the evolution of ethics is a sense of solidarity with other human beings."

Albert Schweitzer

\section{REFERENCES}

1. Activities That Require IRB Review. Research.uci.edu. N.p., 2017. Web. 19 May 2017. Available from: http://www.research.uci.edu/compliance/human-research-protections/researchers/activitiesirb-review.html

2. Heard, Andrew. Introduction To Human Rights Theories. Sfu.ca. N.p., 2017. Web. 19 May 2017. Available from: http://www.sfu.ca/ aheard/intro.html

3. Revolvy, LLC. Genetic Studies Of Genius. On Revolvy.Com". Revolvy.com. N.p., 2017. Web. 19 May 2017. 
4. Nurius PS, Prince DM, Rocha A. Cumulative Disadvantage And Youth Well-Being: A MultiDomain Examination with Life Course Implications. Child Adolesc Soc Work J 2015;32(5):567-76.

5. Pain, Suffering, And The History Of Human Experimentation. Healthline. N.p., 2017. Web. 19 May 2017. Available from: http://www.healthline.com/health-news/strange-the-sordid-history-of-humanexperimentation-101213.

6. The 30 Most Disturbing Human Experiments In History. Bestpsychologydegrees.com. N.p., 2017. Web. 19 May 2017. Available from: http://www.bestpsychologydegrees.com/30-most-disturbinghuman-experiments-in-history/

7. Owens B. Long-Term Research: Slow Science. N.p., 2017. Print. Available from: http://www.nature.com/news/long-term-research-slow-science-1.12623

8. Jarmusik N. Nuremberg Code (1947). Imarcresearch.com. N.p., 2017. Web. 19 May 2017.

9. Ghooi RB. The Nuremberg Code-A Critique. Persp Clin Res 2011;2: 72-5.

10. Keiger D, Pasquale SD. Trials \& Tribulation. John Hopkins Magazine. 2017. Available from: http://pages.jh.edu/jhumag/0202web/trials.html

11. Unethical Clinical Trials Still Being Conducted In Developing Countries. The Huffington Post. N.p., 2017. Web. 19 May 2017. Available from: http://www.huffingtonpost.com/michael-caromemd/unethical-clinical-trials_b_5927660.html

12. Wainwright $\mathrm{O}$. The End Of Animal Testing? Human-Organs-On-Chips Win Design Of The Year. The Guardian. 2017. Web. 19 May 2017. Available from: https://www.theguardian.com/artanddesign/2015/jun/22/the-end-of-animal-testing-human-organson-chips-win-design-of-the-year.

***************************************

Acknowledgements - Nil

Source of Funding - Nil

Conflict of Interest $-\mathrm{Nil}$ 